\title{
Research of crack initiation and propagation under loading for providing impact resilience of protective coating
}

\author{
O.O.Sapronov ${ }^{1}$, A.V.Buketov ${ }^{1}$, P.O.Maruschak ${ }^{2}$, S.V.Panin ${ }^{3,4}$, \\ M.V.Brailo ${ }^{1}$, S.V.Yakushchenko ${ }^{1}, A . V . S a p r o n o v a^{1}$, \\ O.V.Leshchenko ${ }^{1}$, A.Menou ${ }^{5}$ \\ ${ }^{1}$ Kherson State Maritime Academy, 20 Ushakov Ave., \\ 73009 Kherson, Ukraine \\ ${ }^{2}$ Ternopol I. Pul'uj National Technical University, \\ 56 Ruska Ave., 46001 Ternopil, Ukraine \\ ${ }^{3}$ Institute of Strength Physics and Materials Science Siberian Branch of \\ the Russian Academy of Sciences, 2/4 Academicheskii Ave., 634055 \\ Tomsk, Russia \\ ${ }^{4}$ National Research Tomsk Polytechnic University, \\ 30 Lenin Ave., 634050 Tomsk, Russia \\ ${ }^{5}$ International Academy of Civil Aviation, Casablanca, Morocco
}

\section{Received September 12, 2018}

The analysis of destruction process under the impact loading of developed epoxy composites with different content of carbon nanotubes is carried out. Introduction of nanoparticles into the epoxy binder at the optimal content of $q=0.010 \mathrm{pts} \cdot \mathrm{wt}$. allows 3 times increase of impact resilience relative to the epoxy matrix. The loading value at the moment of material destruction, the value of critical strain and the crack propagation rate in time to the materials destruction on the impact testing machine RKP-300 for highspeed loading are established. By the method of optical and electron microscopy it is established that the uniformity of particles distribution of carbon nanotubes influences the morphology of nanocomposites, and hence the properties of the formed materials.

Keywords: carbon nanotubes, impact resilience, fracture surface, crack propagation.

Проведен анализ процесса разрушения при ударной нагрузке разработанных эпоксидных композитов с различным содержанием углеродных нанотрубок. Введение наночастиц в эпоксидное связующее при оптимальном содержании $q=0,010$ мас.ч. позволяет повысить ударную вязкость в 3 раза относительно эпоксидной матрицы. Установлено значение нагрузки в момент разрушения материала, значение критической деформации и скорость распространения трещины во времени до разрушения материалов на копре RKP300 высокоскоростной нагрузки. Методами оптической и электронной микроскопии установлено, что равномерность распределения частиц углеродных нанотрубок влияет на морфологию нанокомпозитов, а следовательно, и свойства сформированных материалов.

Дослідження особливостей зародження і поширення тріщин при навантаженні для забезпечення ударної в'язкості захисних покриттів. О.О.Сапронов, А.В.Букетов, П.О.Марущак, С.В.Панін, М.В.Браӥло, С.В.Якущенко, А.В.Сапронова, О.В.Лещенко, А.Мену.

Проведено аналіз процесу руйнування при ударному навантаженні розроблених епоксидних композитів із різним вмістом вуглецевих нанотрубок. Введення наночасток 
у епоксидний зв'язувач за оптимального вмісту $q=0,010$ мас·ч. дозволяє підвищити ударну в'язкість у 3 рази відносно епоксидної матриці. Встановлено значення навантаження у момент руйнування матеріалу, значення критичної деформації та швидкість поширення тріщини у часі до руйнування матеріалів на копрі RKP-300 високошвидкісного навантаження. Методами оптичної та електронної мікроскопії встановлено, що рівномірність розподілення часток вуглецевих нанотрубок впливає на морфологію нанокомпозитів, а отже і властивості сформованих матеріалів.

\section{Introduction}

Demand for polymeric materials is growing rapidly every year both in the world. Nowadays, a number of scientific researches [1-8] are published, where it is stated that polymeric materials according to operational characteristics compete with high-deficient metals and alloys. Due to the polymer operating features it is used both as thermoplastics and thermosetting material. Surely, the physical-mechanical and thermophysical properties of filled thermoplastics enormously exceed the therrnosetting material [7-12]. At the same time, taking into account an urgent need of protection of technological equipment and metal structures from corrosion in various industries - thermosetting material are ahead, because the coatings on their basis are characterized by high adhesion strength (that reaches $76 \mathrm{MPa}$ ), corrosion resistance, sufficient elasticity and wear resistance [4-6]. At the same time, the simplified coating technology (pulverization method) on the basis of therrnosetting material allows to cover the multidimensional surfaces of configuration while the use of thermoplastics for protective coating is limited by the conditions of formation (casting, tableting).

Taking into account mentioned above comparison, as well as polymer operational features, it is relevant to develop a protective coating on the basis of filled therrnosetting material with a complex of improved properties for sea and river transport.

\section{Experimental}

The epoxy diane oligomer (ED-20 grade, State standard "GOST 10587-84") was chosen as the basic binder component under the Polymer Composite Material (PCM) formation. It is characterized with a set of improved properties in comparison with other spread thermoset materials. Among them are: high adhesive bonding to metal substrates; ability of running curing process at low temperatures; lack of volatile organic emissions at product formation, easy processibility as well as low coating shrinkage at deposition onto long-length surfaces of complex profile parts. The molecules of epoxy oligomers contain glycidyl and epoxy groups that can interact with curing agents to form cross-linked structure in the form of a net. All these result in substantially improving of the PCM characteristics.

The curing agent polyethylene polyamine PEPA (Industrial Standard "TU 6-05-241202-78") was used for cross-linking of the epoxy composites. It allows running curing process at room-temperatures. As is known from the literature the PEPA is a low-molecular substance that consists of such structural monomeric units: $\left[-\mathrm{CH}_{2}-\mathrm{CH}_{2}-\mathrm{NH}-\right]_{n}$. Different stages of cross-linking were varied and investigated under loading of the curing agent into composite at the following mixing rate of the components: $10 \mathrm{pts} \cdot \mathrm{wt}$. on 100 pts.wt. of epoxy oligomer ED-20.

To ensure the stability of protective coatings for shock loads that occur during the operation, the use of carbon nanotubes (CNT) is foreseen. Despite the high mechanical strength of carbon nanotubes, they are resistant to critical strain bending, stretching, compression. At the same time, due to the high specific surface area and adsorption capacity, the introduction of CNT at optimal content will allow for a change in the structure of the polymer, and hence the ability to counteract the shock loads. The size of the CNT nanoparticles ( $d=5 \mathrm{~nm}$ ), was determined by the method of electron microscopy. The filler content was varied in the range $q=0.010 \ldots 0.100 \mathrm{pts} \cdot \mathrm{wt}$.

The following technique was employed for mixing carbon nanotubes with epoxy composites: I) preliminary dosage of the epoxy diane resin ED-20; II) heating of the resin up to the temperature $T=(353 \pm 2) \mathrm{K}$ and exposure at this temperature during $\tau=(20 \pm 0.1) \mathrm{min}$; III) dosage of the filler and its further loading into epoxy binder; IV) hydrodynamic combining of the oligomer ED-20 and nano-filler during $\tau=(1 \pm 0.1)$ min; V) ultrasonic processing of the composition during $\tau=(1.5 \pm 0.1) \mathrm{min}$; VI) cooling of the composition down to the ambient temperature during $\tau=(60 \pm 5) \mathrm{min}$; VII) loading of the curing agent PEPA and mixing of the composition during $\tau=(5 \pm 0.1) \mathrm{min}$. Then the curing of the PCM was conducted under the experimentally determined mode: I) formation of the samples and their curing 
during $\tau=(12.0 \pm 0.1) \mathrm{h}$ at the temperature $T=(293 \pm 2) \mathrm{K}$; II) heating with the rate of $\mathrm{v}=3 \mathrm{~K} / \mathrm{min}$ up to the temperature $T=$ $(393 \pm 2) \mathrm{K}$; III) strengthening of the PCM during $\tau=(2.0 \pm 0.05) \mathrm{h}$, IV) slow cooling down to the temperature $T=(293 \pm 2) \mathrm{K}$. To stabilize structural processes to occur in the PCM they were exposured (strengthened) during $\tau=24 \mathrm{~h}$ in the open air at the temperature $T=$ (293 \pm 2$) \mathrm{K}$ before testing.

Fracture surface topology of the impact bending failured PCM were investigated with the help of optical and scanning electron microscopy.

The impact toughness was measured with the use of notchless specimens with the sizes of $10 \times 15 \times 75 \mathrm{~mm}^{3}$. The tests were carried out with the use of impact pendulum machine RKP-300 under high-rate loading $(5.2 \mathrm{~m} / \mathrm{s})$. In doing so, the loading diagrams "loading-time" and "loading-bending reflection" were registered. A total work of impact fracture $A$ is composed of two components: i) crack initiation $A_{i}$ and ii) crack propagation $A_{p}$.

The impact toughness was determined as:

$$
W=\frac{A}{b s},
$$

where $A$ is the impact energy, consumed for the specimen fracture; $b$ is a width of a sample; $s$ is a thickness of a sample.

The use of the impact loading diagram processing software "VUHI-CHARPY" made it possible to determine fracture energy components by transforming "force - time" $(P-t)$ dependence into "force - displacement" $(P-s)$ one.

\section{Results and discussion}

Previously, the comparison of impact resilience parameters of epoxy composites with different CNT particles content was made. It is established that value of impact resilience of epoxy matrix is $W=0.7 \mathrm{~J} / \mathrm{cm}^{2}$ (Fig. 1, curve 1).

At introducing of CNT particles at content $q=0.010 \mathrm{pts} \cdot \mathrm{wt}$. into epoxy binder, a rapid increase of composite material impact resilience value up to $W=1.60 \mathrm{~J} / \mathrm{cm}^{2}$ is observed. Taking into account formation conditions (ultrasound dispersion) and nanoparticles structure (each $s p 2$ atom is hybridized and bound to three neighboring atoms of hexagonal pattern that form cylindrical structures with different amount of concentric cylinders), it is reasonable to assume that the rapid increase of impact resilience

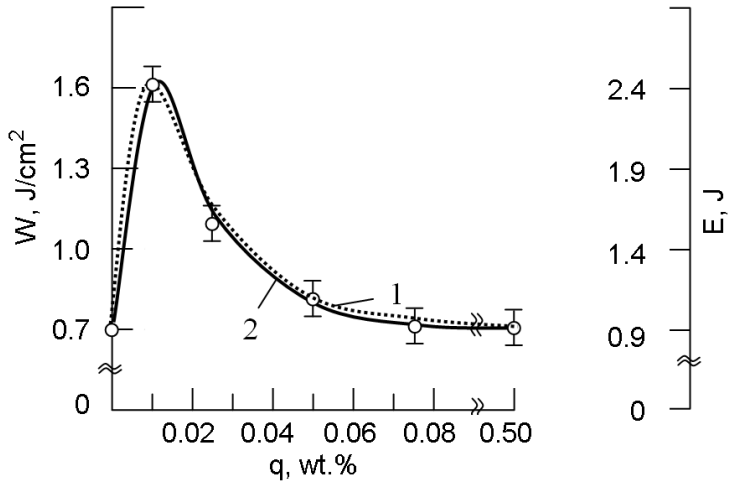

Fig. 1. Dependence of impact resilience $(W)$ and energy $(E)$, that is consumed on the materials destruction, on CNT contents: 1 impact resilience; 2 - energy consumed on the materials destruction.

is due to a significant adsorption interaction of polymer and a filler, when the interaction forces at the interface "polymernanoparticle" enable the deployment of polymeric molecule. Thus, the physical-chemical interaction, and hence the growth of the impact resilience are provided. Accordingly, the energy consumed on the composite destruction under the impact loading reaches maximum value of $E=2.4 \mathrm{~J}$, which is confirmed by the study results given in Fig. 1, curve 2 .

Introduction of $\mathrm{CNT}$ particles in the range of $q=0.025 \ldots 0.500 \mathrm{pts} \cdot \mathrm{wt}$. provides a monotonous decrease of composite materials (CM) impact resilience parameters $(W=$ $\left.1.20 \ldots 0.7 \mathrm{~J} / \mathrm{cm}^{2}\right)$ and, accordingly, the energy $(E=1.5 \ldots 0.9 \mathrm{~J})$ consumed on the composites destruction (Fig. 1, curve 1, 2). The analysis of researches [1-5] allows to state that high surface energy and nanosize of CNT particles result in formation of agglomerates (from tens to hundreds of micrometers), which prevents the uniform distribution of CNT in the matrix and achievement of maximum polymer modification efficiency. Obviously, this can explain a decrease of parameters of the impact resilience and, accordingly, the energy consumed on the impact.

To evaluate the peculiarities of the crack initiation and propagation under the impact loadings, it is considered expedient to analyze the change in loading $(P)$ in time (Fig. 2,a) and the dependence of CM deformation $(\Delta l)$ on the loading $(P)$ (Fig. 2,b). It is established $[13,14]$, that the destruction of epoxy composites under the impact loading occurs in several stages: the process of crack initiation (I), its propagation (II) and the direct destruction of materials (III). 

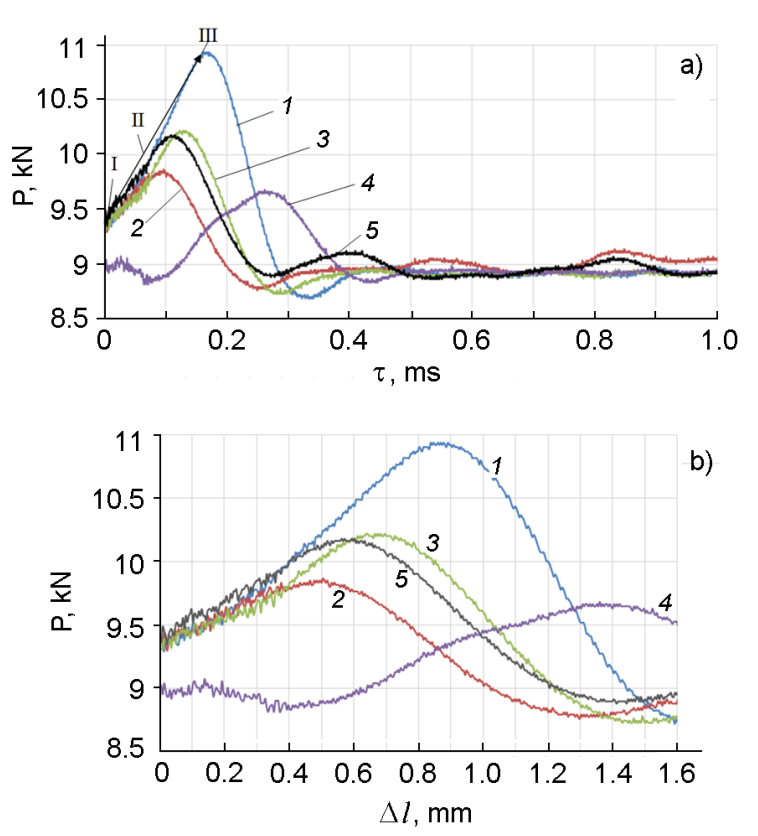

Fig. 2. Dependences of crack propagation rate on loading (a) and inflection from loading (b) CM with different CNT particles content, $q$, pts.wt.: $1-0.010 ; 2-0.025 ; 3-0.050$; $4-0.075 ; 5-0.100$.

Analysis of the dependence of loading on the duration of impact of CM with particles of CNT at content $q=0.010 \mathrm{pts} \cdot \mathrm{wt}$. shows that for NCM the maximum loading at the moment of sample destruction increases in $\Delta P=0.8 \mathrm{kN}$, in comparison with the polymer matrix, and the time of crack propagation is shifted to the right on the abscissa axis in $\Delta \tau=0.07 \mathrm{~ms}$ (in comparison with the epoxy matrix) (Fig. 2,a, Table). Consequently, the physical-chemical processes in the epoxy oligomer at the presence of nanodispersed component at optimal content results in the formation of a nanocomposite with maximum resistance to critical bending and impact strain. Additionally, the fracture surface of material with CNT particles ( $q=0.010 \mathrm{pts} \cdot \mathrm{wt}$.) is characterized by the presence of a transitional (viscous and brittle) chaotic fracture throughout of all the composite perimeter (Fig. 3,a).

The analysis of researches [3-5] indicates that CNT parameters in the polymer matrix differ significantly from the parameters of nanotubes in a free state. The persistent length decreases twice, and the fractal dimension increases with the influence of ultrasonic dispersion. In turn, the decrease of persistent length of flexible CNT indicates on the increased flexibility of nanocomposite in general. An additional confirmation of the above statements is the received value of critical strain. Consequently, the maximum value of critical strain among the studied NCM is $l=$ $0.90 \mathrm{~mm}$ (for NCM with the CNT content $q=$ 0.010 pts.wt.), which is on $\Delta l=0.35 \mathrm{~mm}$ higher in comparison with the epoxy matrix. That is, the transient nature of destruction is observed when at a sufficient polymer elasticity (due to the flexibility of the nanodispersed component) critical loadings dominate at the moment of destruction. In this case, the CNT particles in the formed polymer network serve as a barrier of crack propagation.

At introduction of CNT particles at content $q=0.025 . .00 .050 \mathrm{pts} \cdot \mathrm{wt}$. into epoxy binder, the decrease of the loading value at the moment of $\mathrm{CM}$ destruction to $P=$ 9.8..10.3 $\mathrm{kN}$ and the time of crack propagation up to $\Delta \tau=0.50 \ldots 0.70 \mathrm{~ms}$ is observed (Fig. 2,a, Table 1). Taking into account the possibility of forming agglomerates in a binder at the presence of CNT with significant surface energy, deterioration of the studied parameters $(P, \tau)$ is observed.

Additional confirmation of the above statements is the fracture pattern of given NCM. For CM with CNT content $q=0.025$ pts.wt., viscous nature of destruction, which in most cases indicates the elastic properties of the material is observed (Fig. 3,b). However, for the given CNT content, a decrease of the impact resilience values and parameters $(P, \tau)$ is

Table. Characteristic parameters $P, P^{\prime}, \tau$ and $l$ of the nanocomposites fracture

\begin{tabular}{||c|c|c|c|c||}
\hline $\begin{array}{c}\text { Nanofiller content } \\
(\mathrm{CNT}), q, \mathrm{pts} \cdot \mathrm{wt} .\end{array}$ & $\begin{array}{c}\text { Loading on cracks } \\
\text { initiation, } P, \mathrm{kN}\end{array}$ & $\begin{array}{c}\text { Maximal loading } \\
\text { prior to fracture, } \\
P^{\prime}, \mathrm{kN}\end{array}$ & $\begin{array}{c}\text { Time of crack } \\
\text { propagation } \tau, \mathrm{ms}\end{array}$ & $\tau, \mathrm{ms}$ \\
\hline Matrix & 9.4 & 10.0 & 0.10 & 0.55 \\
0.010 & 9.4 & 10.8 & 0.18 & 0.90 \\
0.025 & 9.4 & 9.80 & 0.10 & 0.50 \\
0.050 & 9.4 & 10.3 & 0.13 & 0.70 \\
0.075 & 9.0 & 9.60 & 0.25 & 1.40 \\
0.100 & 9.4 & 10.2 & 0.11 & 0.60 \\
\hline
\end{tabular}



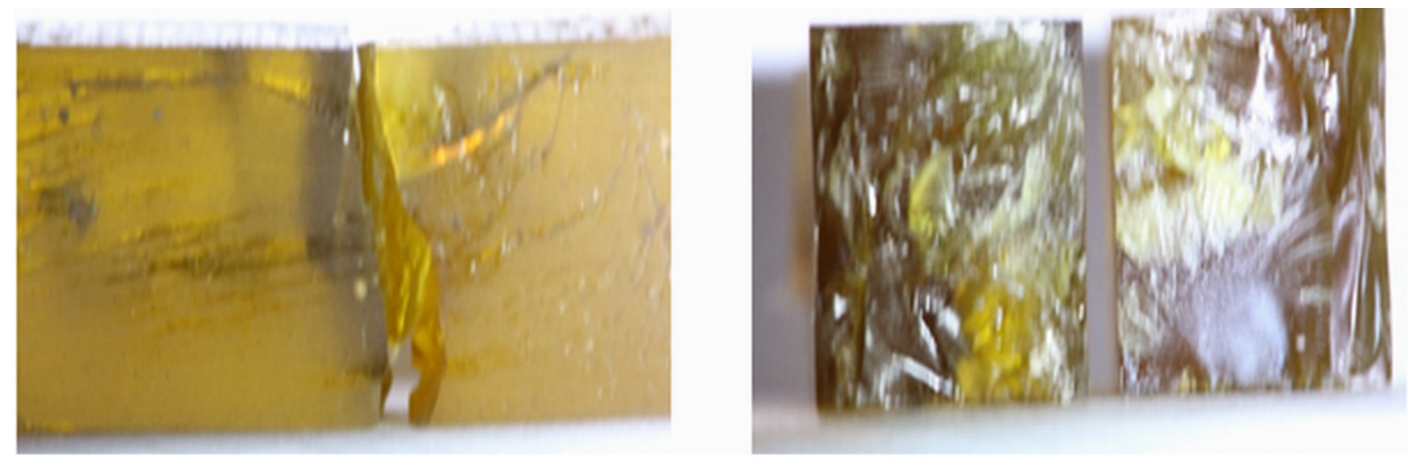

a)
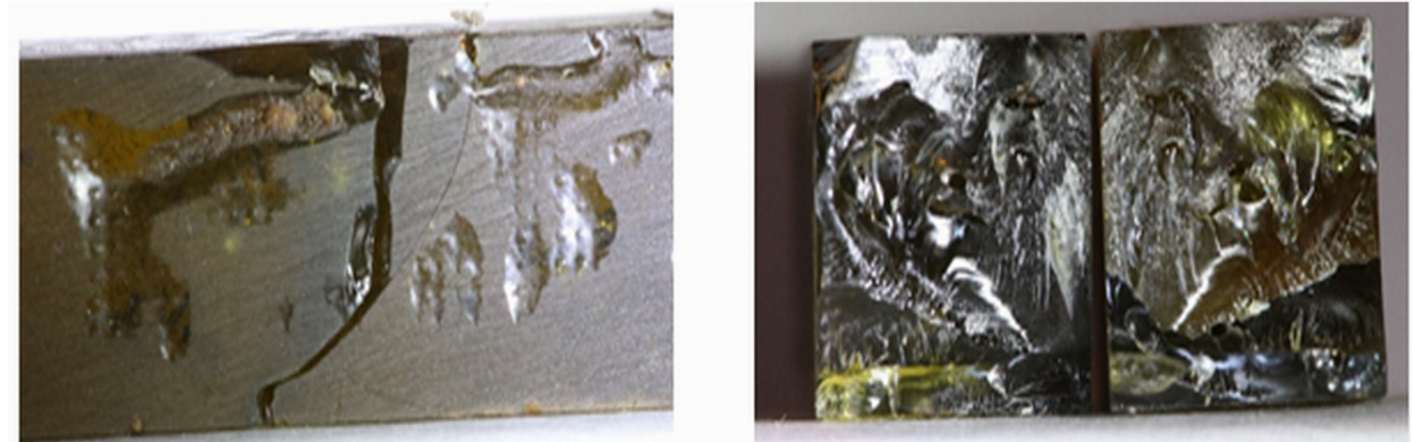

b)
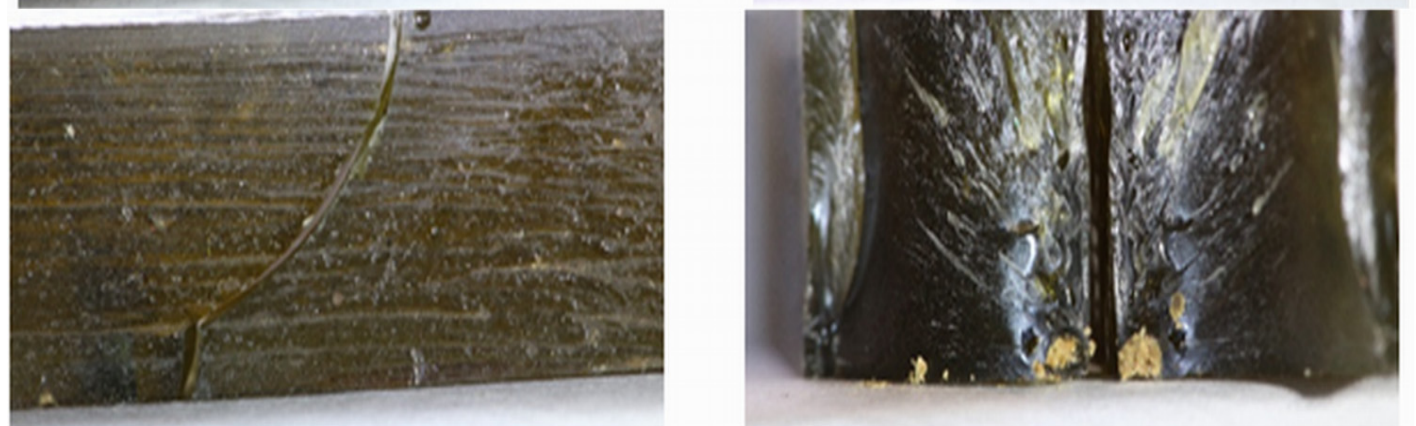

c)
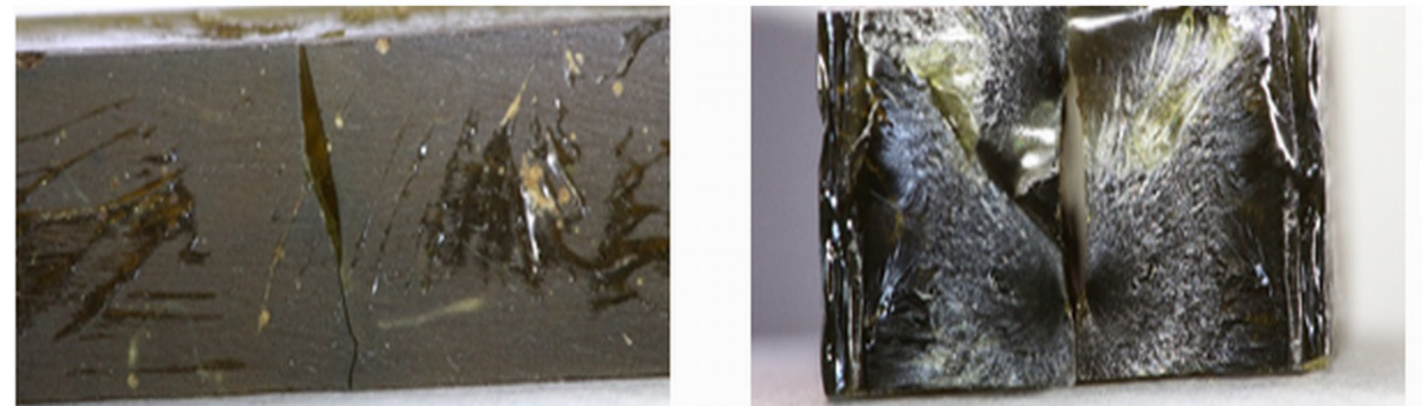

d)

Fig.3. View of macro destruction of epoxy composites filled with nanotubes particles.

q, pts.wt.: a),b) 0.010 ; c), d) 0.025 ; e), f) 0.050 .

observed, which may indicate the presence of micropores in the polymer structure that are acting as strain concentrators. At the same time, at CNT content $q=0.050 \mathrm{pts} \cdot \mathrm{wt}$, the presence of impurities is observed (Fig. $3, \mathrm{c})$, which leads to decrease of the loading value at the time of destruction, which in turn leads to a decrease of crack propagation time, and hence a decrease of impact resilience. Accordingly, such NCM are characterized by in- significant values of critical strain $l=0.50 \ldots 0.70 \mathrm{~mm}$.

Further increase of CNT content ( $q=0.075 \ldots 0.100 \mathrm{pts} \cdot \mathrm{wt}$.$) leads to decrease$ of parameters $P, \tau, l$ (Fig. 2, Table) due to the formation of a defective structure is the polymer volume. Respectively, at the crack propagation with high rate during the impact, such NCM are easily perished. That is, such materials are characterized by a ki- 


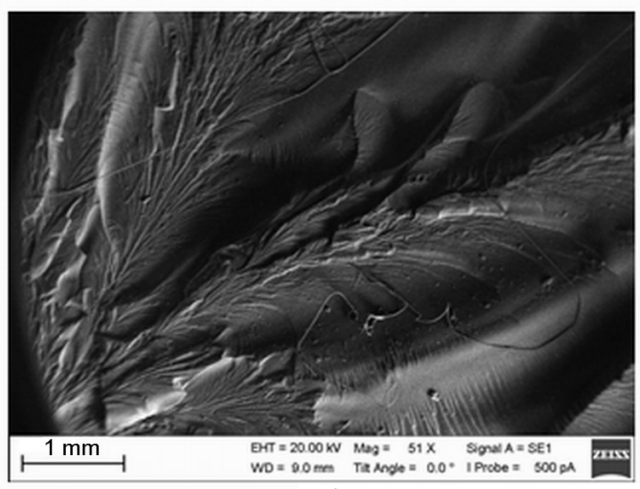

a)

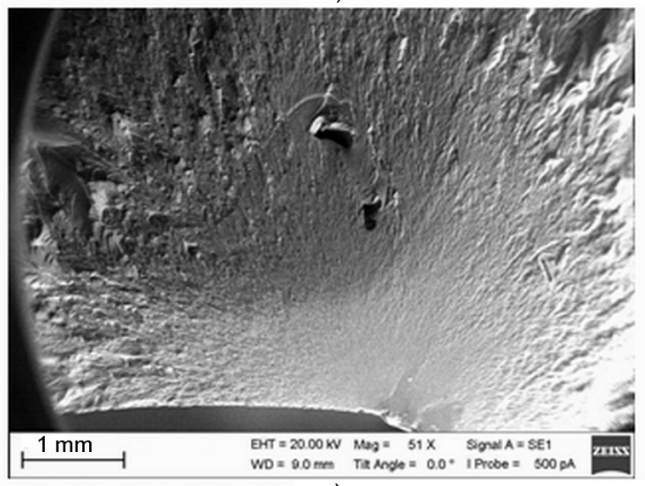

c)

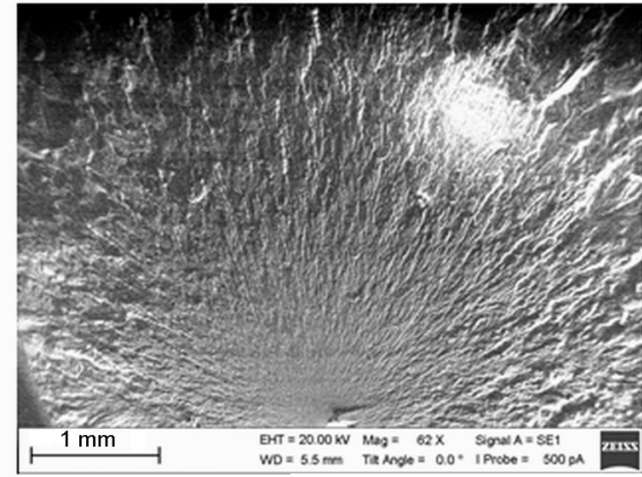

e)

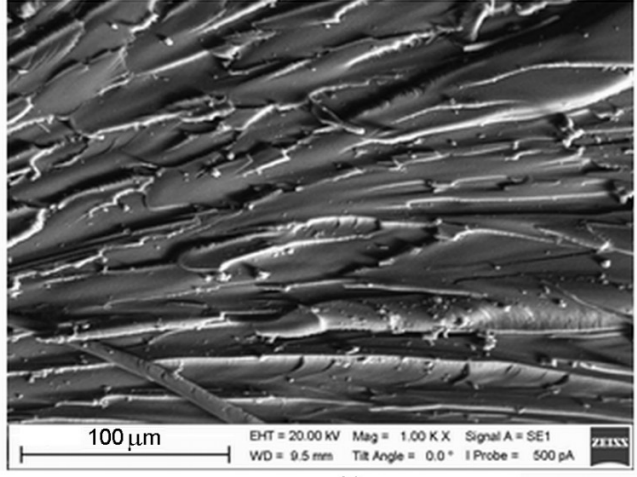

b)

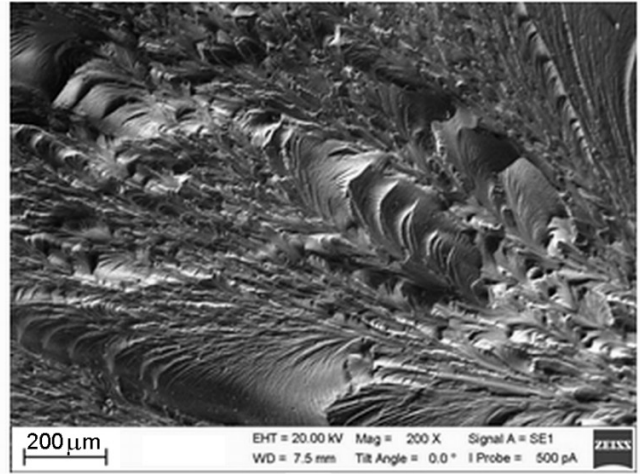

d)

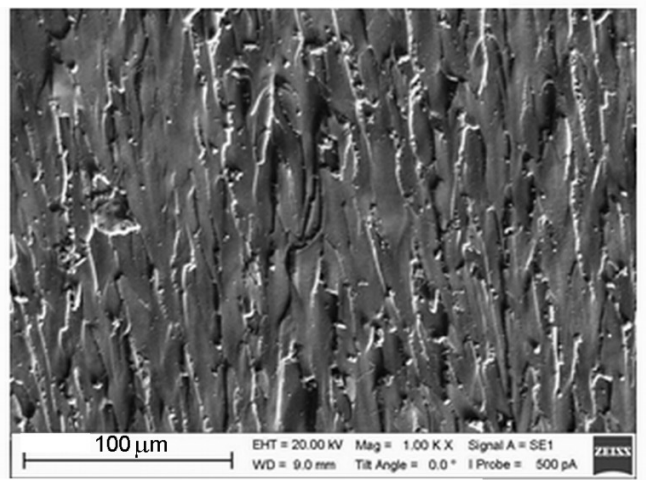

Fig. 4. Electronic micrograps of fracture of epoxy composite with different content of nanotube particles. $q$, pts.wt.: a),b) 0.010 ; c), d) 0.075 ; e), f) 0.050

netic unbalanced state of a heterogeneous polymer system. Particular attention is paid to the loading values at the moment of material destruction and the time of crack propagation for CM with CNT content $q=$ $0.075 \mathrm{pts} \cdot w t$. (Table). Obviously, that at the time of material destruction, a crack appears (due to structural defects) with subsequent destruction of the CM.

According to the IR spectral analysis [5, 15] and the presented results of the study, it can be argued that the growth of the impact strength of the developed material is due to the activation of epoxy groups, the growth of the number of hydroxyls, and the formation of a small number of carbonyl groups in the original oligomer. The confirmation of the above-mentioned theses is the growth of the parameters of intensity of adsorption bands $(T, \%)$ and area $(S, \%)$ of absorption bands at wave numbers $v=$ 2873.84...3498.87 $\mathrm{cm}^{-1}$ for CM with CNT particles at the content $q=0.010 \ldots 0.050 \mathrm{pts} \cdot \mathrm{wt}$.

For a detailed analysis of the formed material structure, the REM images of the destruction surface of studied NCM are given in the research. It was considered appropriate to point out the results of research of surface of NCM destruction with the maximum value of the impact resilience and the 
values $P, \tau, l$ (CM with the CNT content $q=$ $0.010 \mathrm{pts} \cdot \mathrm{wt}$.), and also with the maximum CNT content $(q=0.075 \ldots 0.100 \mathrm{pts} \cdot \mathrm{wt}$.). It is established that the uniform distribution of CNT particles affects the nanocomposite morphology, and hence the properties of the formed materials (Fig. 4). During the analysis of fracture pattern of CM with the CNT content $q=0.010 \mathrm{pts} \cdot \mathrm{wt}$. (increased $\times 51$ ), a uniformly structured fracture surface without any defects is observed. With an increase of $\times 1000$, linear formations of a branched-shaped chip in a size of $\approx 100 \mathrm{~nm}$ is observed (Fig. 4,b). It is possible to assume that the direction of cracks propagation is oriented along the persistent length of CNT particles. Then the increase of impact resilience index is connected with an increase of density of the physical nodes of bonding network, as well as with the presence of chemical bonds that block the growth and propagation of cracks in a complex.

Analysis of the REM image of the destruction surface of NCM with a content $q=$ $0.075 \mathrm{pts} \cdot \mathrm{wt}$. at an increase of $\times 51$ (Fig. 4,c) and NCM with a content $q=0.100$ pts.wt. at an increase of $\times 62$ (Fig. 4,e) allows to detect defects of structure in the form of micropores. With an increase in the surface of the destruction of NKM to $\times 1000$ (Fig. $4, \mathrm{~g}$ ), the presence of heterogeneity in the form of influxes and depressions with chaotic direction of the propagation of cracks was observed. This indicates the presence of agglomerates in the structure of the polymer, and therefore the insignificant impact strength of the material.

At an increase of the NCM destruction surface to $\times 1000$ (Fig. 4,d), the presence of heterogeneity in the form of runs and curves with chaotic direction of crack propagation is observed. This indicates the presence of agglomerates in the polymer structure, and therefore the insignificant impact resilience of the material.

\section{Conclusions}

The dynamics of destruction of epoxy composites filled with carbon nanotubes under the impact loading is investigated in this research. It is also established:

Due to the resistance to critical bending strains (critical strain value among the studied $l=0.90 \mathrm{~mm}$ ) and the loading, epoxy composites with an optimal CNT content $q=$ $0.010 \mathrm{pts} \cdot \mathrm{wt}$. are characterized by increased values of impact resilience $W=1.60 \mathrm{~J} / \mathrm{cm}^{2}$ and, accordingly, the energy consumed to the material destruction $-E=2.4 \mathrm{~J}$.

The analysis of the destruction process of the developed nanocomposites under impact loading is carried out. It is established that at maximum loading, $P=10.8 \mathrm{kN}$, epoxy composites with CNT particles at content $q=0.010 \mathrm{pts} \cdot \mathrm{wt}$. are characterized by the ability to deform to $l=0.90 \mathrm{~mm}$ (till the time of destruction). And the maximum value of the time of crack propagation is on $30 \ldots 40 \%$ greater in comparison with the epoxy matrix and investigated NCM, which confirms the ability of the developed materials to resist bending and impact strains.

Analysis of the fracture pattern obtained by optical and electron microscopy allows to state that the increase of impact resilience is connected with the formation of a uniform polymer structure, which is provided by an increase of the density of physical nodes of bonding network, as well as with the presence of chemical bonds that block the growth and the propagation of cracks in the a complex.

\section{References}

1. O.Sapronov, P.Maruschak, N.Buketova et al., in: AIP Conf. Proc. Advanced Materials with Hierarchical Structure for New Technologies and Reliable Structures, Tomsk, Russia (2016).

2. A.V.Buketov, O.O.Sapronov, M.V.Brailo, V.L.Aleksenko, Mater. Scie., 49, 696 (2014).

3. Yu.V.Suvorova, S.I.Alekseeva, M.A.Fronya, I.V.Viktorova, Diagnostika Mater., 78, 1357 (2013).

4. E.A.Lysenkov, V.V.Klepko, V.M.Golovanets, V.L.Demchenko, Ukr.J.Phys., 59, 906 (2014).

5. A.Buketov, P.Maruschak, O.Sapronov et al., Mol. Cryst. Liq. Cryst., 628, 167 (2016).

6. A.Buketov, P.Maruschak, O.Sapronov, D.Zinchenko et al., Transport, 31, 333 (2016).

7. N.G.Leonova, V.M.Mikhal'chuk, Y.P.Mamunya et al., Polymer Sci. Ser. D, 6, 210 (2013).

8. R.V.Dinzhos, N.M.Fialko, E.A.Lysenkov, J.of Nano-Electron. Phys., 6, 01015-1 (2014).

9. E.A.Lysenkov, V.V.Klepko, I.P.Lysenkova. J. Phys. Stud., 21, 4701-1 (2017).

10. E.A.Lysenkov, Z.A.Haholkina, E.V.Lobko et al., Mater. Sci., 53, 14 (2017).

11. A.V.Buketov, N.A.Dolgov, A.A.Sapronov et. al., Strength Mater., 49, 473 (2017).

12. A.V.Buketov, N.A.Dolgov, A.A.Sapronov, V.D.Nigalatii, Strength Mater., 50, 425 (2018).

13. A.V.Buketov, A.A.Sapronov, N.N.Buketova et al., Composites: Mechan, Computat., Applicat., 9, 157 (2018).

14. A.V.Buketov, A.O.Sapronov, M.V.Brailo et al., Mech. Adv. Mater. Struct., 1537-6532, 1 (2018).

15. .V.Buketov, A.V.Sapronova, O.V.Leshchenko et al., Naukovi Notatky, 61, 13 (2018). 